\title{
Sustainable development policies and the spread of land-sharing practices - a statistical assessment in a frontier region of the Brazilian Amazon
}

Xavier Arnauld de Sartre ${ }^{1}$, Johan Oszwald ${ }^{2}$, Iran Veiga ${ }^{3}$, Monica Castro ${ }^{1}$, William Assis ${ }^{3}$, Fernando Michelloti ${ }^{4}$, Carla Rocha ${ }^{3}$, Haroldo Souza ${ }^{4}$, Pascal Sebille ${ }^{5}$, Sylvain Dolédec ${ }^{6}$, Patrick Lavelle $^{7}$

(1) Centre national de la recherche scientifique, Univ Pau \& Pays Adour, UMR 5603 - SET Société Environnement Territoire

IRSAM - Avenue du Doyen Poplawski - PAU, F- 64000, France

Phone: +33659027511

Email:

- $\quad$ xavier.arnauld@,cnrs.fr

- monica.castro@,univ-pau.fr

(2) Université Rennes 2, UMR LETG (UMR CNRS 5654),

5 place Henri Le Moal, 35000, RENNES, France

Email: johan.oszwald@uhb.fr

Universidade Federal do Pará (UFPA), Núcleo de Ciências Agrárias e Desenvolvimento Rural (NCADR)

Rua Augusto Corrêa, 01 - Guamá

66075-110 Belém PA, Brazil

Email:

- veiga@ufpa.br

- william.assis@ufpa.br

- crocha@ufpa.br

(4) Universidade Federal do Pará (UFPA), Campus de Maraba

Floha 17, Quadra e lote especial, Campus II da UFPA, CEP 68.505-80, Marabá, Pará, Brazil

Email:

- fmichelotti@ufpa.br

- haroldosou@gmail.com

(5) Université Paris Ouest Nanterre La Défense (Paris 10), Centre de recherche Populations et Sociétés (EA),

200 avenue de la République, 92001 Nanterre Cedex, France

Email: pascal.sebille@u-paris10.fr

(6) Université Lyon 1, LEHNA, UMR Biodiversité des écosystèmes lotiques (UMR 5023),

Bâtiment Florel, 6 rue R. Dubois, 69622 Villeurbanne Cedex, France

Email: Sylvain.Doledec@univ-lyon1.fr

(7) Université P. et M. Curie (Paris 6), UMR BIOEMCO 7618, Centre IRD Ile de France, 32 rue Henri Varagnat, 93143 BONDY, France

Email: Patrick.Lavelle@ird.fr 


\section{Higlitghts}

- In Brazilian Amazon, socio-environmental movement follow the land reform process

- This process leads to promote land sharing agriculture (LShA) for family farmers

- But LShA projects might have impacts opposed to the planed objectives

- And can lead to a land sparing organization of space

- Success of such LShA project is related to the context in which farmers are embedded

\section{Introduction}

The "land-sharing" versus "land-sparing" debate is useful for conceptualizing the choices made by policy makers in the agricultural sector to satisfy demand for food at the least cost to the environment (Green et al., 2006; Phalan et al., 2011). While "land-sparing" seeks to develop agriculture in areas most suited to this purpose, with specific areas set aside exclusively for conservation purposes, the aim of "land-sharing" is to develop agricultural systems where conservation and production coexist.

Many studies have shown that the opposition between conservation and development (represented in the land-sparing strategy) will become counter-productive in the long term, and that new forms of governance and action must be found to ensure that Amazonia can continue to deliver a range of environmental services in the future (Davidson et al., 2012) while also fulfilling various social and economic functions (Rodrigues et al., 2009). Even in areas mostly dedicated to food production, alternative agricultural systems are needed.

The situation in the Brazilian Amazon illustrates this necessity. From the 1990s to mid-2010, the Amazonian landscape came under conflicting management practices: on the one hand, conservationgeared projects seeking to create more protected areas (Soares Filho et al., 2006), and on the other hand, policies looking to integrate the Amazon into the dynamics of capitalism, which are characterized by severe impacts on the Amazonian forest (Laurance et al., 2001). In the Brazilian Amazon, the conflict was partially resolved by partitioning the region into areas of different types: areas dedicated to conservation, areas dedicated to production ("land-sparing" strategy) and areas for sustainable use (geared to "land-sharing"). In the strategy of dividing the Amazonian region into areas managed for different purposes, family farmers in particular were considered as key players for establishing projects within the areas earmarked for sustainable development.

Furthermore, family farmers are also considered as key stakeholders in developing alternative, more environmentally sound agricultural systems. Land-sharing holds out greater potential for sustaining agricultural production because its core principle is the development of alternative agricultural systems, sometimes based on traditional forms of agriculture. The land-sharing strategy could therefore represent an opportunity for family farmers, who depend directly on the fertility of their immediate environment. They are better placed to invent and disseminate forms of development that can reconcile production and conservation objectives.

However, 20 years of sustainable development in the Brazilian Amazon have shown how difficult it is to create and disseminate such innovations (Albaladejo and Arnauld de Sartre, 2005; Le Tourneau and Droulers, 2011). Although this is theoretically more relevant to family farmers than to other players who are less vulnerable to environmental degradation, the relevance is not immediately obvious to them (Brown and Purcell, 2005). Furthermore, it does not necessarily apply to all family farmers, since this social group is made up of people with very different patterns of activity (Arnauld De Sartre, 2006). Family farmers are in a situation that greatly reduces their capacity for defining alternative strategies (De Reynal, Muchagata, Topall and Hébette, 1997) and are very diversely linked to social and political organizations: depending on the location of their farm, the locality where they 
live and the social network they belong to, the reality they experience can be very different. This results in farming systems that are more diverse than expected from the literature (Castellanet et al., 1998; Browder et al., 2004; Pacheco, 2009).

To understand how this diversity affects the dissemination of sustainable farming practices in rural areas, we propose to compare one "regular" and three "sustainable" settlement projects in the Eastern Brazilian Amazon (figure 2). The sustainable development projects were chosen for their characteristics and their main objectives in terms of the issues addressed: social issues, such as land reform, productive issues, such as incentives for extractive production, or socio-environmental issues. In this paper, these projects are characterized through an environmental assessment (land use) and a social assessment (quality of life). The diversity of situations is taken into account through the family profiles characterized, farm characteristics and the sociopolitical history of each project.

In this paper, we first present the context of settlements in the Amazon in general and in the study region in particular (section 1). We then describe the four projects studied and the methodology we applied (section 2). Next, we present the main results of the variables measured (land use dynamics, quality of life, farming systems and family profiles) for each area studied (section 3), which differ from the objectives of the policies applied in the sites. Using statistical methodologies, we then identify the main factors that could explain variations in project outcomes. This leads to a discussion, in section 4, of the main scales and technical and social issues that arise when disseminating sustainable development projects in situations as diverse as those encountered on the Amazon pioneer front.

\section{Sustainable development, family farmers and productive areas in the Amazon}

The presence of unproductive areas of land in the Brazilian Amazon attracts both farmers looking for (more) land and the Brazilian Federal State as it seeks ways of supporting its economic growth and honouring its commitments to agrarian reform. However these "unproductive areas" are also tropical rainforests - ecosystems that are of great importance for their biodiversity, as carbon traps and as the home of traditional populations such as native Amazonian people. The contradictory issues that arise result in numerous conflicts between the different Amazonian projects.

The division of the Amazon into different sub-regions, some dedicated to production, others to conservation, is one way to resolve such conflicts. In its Amazônia Sustentável program (PAS, 2006), the Brazilian Federal State divided Amazonia into zones of five main categories in order to rationalize its management and colonization: zones with a productive structure, either defined or to be defined, zones to be rehabilitated or reorganised, fragile zones, zones for sustainable uses, and protected areas (Figure 1). The productive zones are either zones with a large number of agrarian reform beneficiaries (as in eastern Amazonia), or zones dominated by large cereal or cattle ranching farms.

In areas dedicated to development through agrarian reform, the social category generally described as "family farmers" is supposed to reconcile development (agrarian reform and food production) and conservation objectives. These migrant families, who live and work along the pioneer fronts, are among those responsible for deforestation since their livelihoods depend on farming the lands they have cleared. This is particularly the case in the Eastern Amazon where, since the 1970s, colonization has been organised along federal or state roads (mainly the Transamazonian and the Belém-Brasília roads) and the many secondary roads that branch off the main roads into the forest. After an initial period (1972-76) when family farmer settlements were encouraged and supported by the Federal State, large landowners were given many incentives in the late 1970s and 1980s. This did not discourage family farmers from extending their settlements along the secondary roads; they colonized the forested areas mostly by themselves. This situation led to numerous conflicts that have created a culture of violence in the region (Simmons et al., 2007). The return of democracy in the 1980 s, spread of sustainable development objectives and the increasing demand for agrarian reform account for the renewed interest in family farmers since the 1990s. Sustainable farming practices were developed and disseminated within this region as a strategy to establish, stabilize and strengthen family farming. Large landowners have nevertheless increased their power with the establishment of large development projects in the region, and land conflicts have continued. State sovereignty has 
been reinforced since mid 2000, and the division of the Amazon into different sub-regions, new forest legislation and a strengthened presence of the Federal State have helped to increase both State sovereignty and protest (Arnauld de Sartre and Taravella, 2008).

Our focus here is on the different experiments developed by public actors or NGO in this region, particularly in a zone which has, according to the PAS, "a productive structure defined or to be defined" (as Eastern Amazon, our studied region), and on their degree of success. The experiments are of several kinds, all aiming to increase family farmers' incomes and to protect forest. Although owning a piece of land has long been the ultimate aim of many farmers' plans for migration, it has gradually been realized that some of them farm their lands without restoring soil fertility (especially by establishing poorly managed grazing lands). Others take the opportunity of access to land to increase their patrimoin by selling it on to a large landowner, thereby cancelling out the objective of agrarian reform which was to redifine the land tenure structure. To counter these trends, individual land ownership has sometimes been rejected by the institutions representing family farmers. Forms of common ownership have been developed that greatly reduce possibilities for earning income from real estate, while technical advisors are attempting to invent and disseminate agricultural techniques that preserve the fertility of the environment, in particular by replacing extensive grazing with perennial crops or forest fruits.

In the eastern Amazon, numerous attempts have thus been observed to develop sustainable farming practices that have limited environmental impacts but generate acceptable levels of income for family farmers. The aim is to disseminate land-sharing practices in lands that are mostly dedicated to production.

\section{Study methodology and sites investigated}

Beyond the image of order and rationality projected by the sustainable planning approach for Amazonia, the region is experiencing considerable social tension as well as attempts to invent alternative forms of development, and there are often strong links between the two. We studied four sites located at the boundary between eastern and central Amazonia (three of which have experienced socio-environmental conflicts ending in bloodshed) in order to highlight this alliance between project and reality and to seek out common points in the way sustainable agriculture projects function - or not.

All four study sites are in eastern Amazonia along the PA 150 and BR 230 highways (Figures 1 and 2), and are emblematic of current socio environmental struggles in Brazil. Their characteristics are shown in table form below (Figure 3). We have chosen these sites for their location and for the policies that have been developed in each one. The four sites are located on either side of the deforestation arc (two in eastern Amazonia, where most lands are already deforested, and two in central Amazonia where deforestation is still a highly topical issue) (figure 2). Two of the sites (one in each region) are under proactive policies to support sustainable production while two others are classic pioneer sites for Amazonian colonisation (one with spontaneous settlement and the other under a settlement project).

Figure 3 - Table of the study sites

\begin{tabular}{|l|c|c|}
\cline { 2 - 3 } \multicolumn{1}{c|}{} & $\begin{array}{c}\text { Eastern Amazonia } \\
\text { (deforestation arc) }\end{array}$ & $\begin{array}{c}\text { Central Amazonia } \\
\text { (zone under tension) }\end{array}$ \\
\hline $\begin{array}{l}\text { Sustainable } \\
\text { production project }\end{array}$ & PA Maçaranduba & PDS Boa Esperança \\
\hline Classic colonisation & PA Palmares & Travessão 338-South \\
\hline
\end{tabular}

Each site is described below. 
- The Palmares site is an settlement project characteristic of agrarian reform achieved after a social conflict by dismantling a large landholding. This was achieved by the Landless Peasants' Movement (MST) after the event known as the "Eldorado de Carajás Massacre". In the municipality of that name, nineteen demonstrators who were demanding access to land by blocking the PA 150 road were shot dead by the police. Outrage helped to create de conditions for a more aggressive agrarian reform policy in this region, leading to creation of many new settlement projects, including the Palmares site. This site operates on the classic lines of agrarian reform projects, although material conditions here are considerably better than elsewhere: all the farmers own a 50 ha piece of land but live in an agro-township, using a daily bus service to travel to their fields. Forest clearing is closely supervised and the farmers are supposed to receive personalised technical assistance and credits to finance their investments in production.

The Maçaranduba site, 80 kilometres to the north, was initially colonised by former Brazil nut harvesters (castanheiros) who had taken it over from the previous concession holders. This settlement project was established on the lines of an extractive reserve: land is in theory owned collectively but in practice each family has a concession for exclusive use, tacitally acknowledge by all. The technical assistance provided mainly concerns the extraction of forest products (oil and nuts), but also certain perennial crops. A good deal of deforestation and violence is taking place at the site: in April 2011 two local leaders (a couple that was at the origin of the settlement project) were assassinated following their multiple denunciations of illegal timber felling.

The travessão 338 south site is a typical "spontaneous agrarian reform" site (Hébette, 1996), in the sense that no particular public policy is applied there, not even support in the form of an settlement project. The farmers living there do not have the status of agrarian reform beneficiaries; they receive no particular support and are the most isolated, being between 12 to 24 $\mathrm{km}$ from the main road, making communications with the outside world very difficult, especially during the rainy season.

The fourth site, the Boa Esperança PDS, is one where a very ambitious sustainable development policy has been applied (Arnauld De Sartre, Berdoulay and Lopes, 2011). It is located a few dozen kilometres from the previous site as the crow flies, and was established in the early 2000s in response to pressure from numerous landless famers attracted to this region by the prospect of jobs at the nearby Belo Monte dam site. The settlement project envisaged at the time was intended to be sustainable insofar as deforestation was to be limited as far as possible by acting on its known causes. Thus, livestock farming was sharply curtailed (each family was allowed no more than seven heads of cattle on 5 ha of grazing land), and land is supposed to be collectively owned, farmers having only the right of enjoyment of their plot (although in practice they consider this right of enjoyment as a full property title). To help them develop alternative sources of income, the farmers receive support to establish perennial crops, while timber resources are exploited collectively by the farmers through concessions to a logging company that has to pay a fair price for the wood.

We met farmers representatives involved in the management of each site in order to characterise the pressures exerted, as well as 51 farmers in the first three sites. In these, we used the results of a socio-economic questionnaire to describe the characteristics of families, their sources of income and the main characteristics of their farms. All farms participating in the survey were georeferenced to enable surveys of changes in their land use. Quantitative research methods were less detailed in the fourth site (PDS Boa Esperança), but we were able to characterise the communities living there by other means (such as hired work or receiving incomes from social policies). We nevertheless kept the fourth site in our analysis because it produced information that, as we shall see, help to understand the complexity of sustainable development policies.

\section{Main results}

We characterised four components in the life and farms of the surveyed farmers: land uses, types of production, family profiles and quality of life. 


\section{4-1. Changes in the land use of each site}

We found little difference between the four sites studied in terms of land use changes since they were colonized, which is in contradiction with the fact that different policies are supposed to have been applied.

Figure 4 shows land use trends between 1990 (when colonisation began in one of the sites), 2000 (when colonisation began in the last site) and 2007 (date of our survey), based in each case on the methodology proposed by Oszwald et al. (2010).

The situation in the four sites is fairly comparable as far as land uses are concerned. The Maçaranduba site was colonised first and now has the highest percentage of deforestation $(75 \%$ of the site). Grazing lands cover about $20 \%$ of soils and the remainder is forest regrowth (fallow lands of different kinds or poorly maintained grazing land). Deforestation rates in the 338-south and Palmares sites are similar. At present, about $20 \%$ of the lands are grazed, 20 to $30 \%$ left to fallow and the remainder forested. Deforestation (visible as burned forest) is still proceeding actively in these sites, especially at Palmares, where it has accelerated since agrarian reform was applied there. The fourth site, Boa Esperança, has fared best in terms of conservation: only $30 \%$ of the lands are deforested, with a very small percentage used as pasture.

Up to a point, these findings seem to contradict the stated aims for each site. The overall trend is clearly towards more or less rapid deforestation to establish grazing lands. But except at Boa Esperança, trends in the sites cannot be accounted for by the policies applied there: for example, the 338-South site, which was colonised without any particular recommendations and is therefore closest to the spontaneous pattern in Amazonian pioneer front situations, is better preserved than Maçaranduba, although the latter was settled in accordance with a deliberately and strongly conservationist policy. Its landscapes are more complex than at Palmares, where support is supposed to have been given to diversified agriculture. The forest at Boa Esperança is also better preserved: this is more consistent with the policies applied there, but the fact that the settlement is extremely recent has to be taken into account in the diagnosis.

\section{4-2. Local production systems}

Our analyses of production systems in three of the sites involved questionnaires to all of the farmers present at Maçaranduba, Palmares and 338-South. These provided production figures for two years (2006 and 2007) for each farm and some of their characteristics. The variables used for the analyses are given in Table 1.

Livestock production is dominant, well ahead of annual crops, with perennial crops and extractive production even less important. Therefore, although the agrarian reform sites studied are seeking to encourage types of production other than cattle raising, they only represent $50 \%$ of all agricultural production in terms of value. Extractive activities, which are supposed to be one of the basis of production at Maçaranduba, account for a very small proportion of overall production, as do perennial crops. Livestock production associated with annual crops (often after deforestation) is the predominant pattern.

Based on the quantitative data collected by means of the questionnaire, we analysed these into principal components, as shown in Table 1. One axis of the Principal Component Analysis (containing $22.5 \%$ of the information) distinguishes people earning a substantial income from livestock (in terms of total production and labour productivity) from people with an other activity than agriculture; the second axis (15.5\% of the information) shows the different types of production (livestock versus perennial crops). The third axis (11.5\%) distinguishes crop farmers, according to the size of their farms, how long they have farmed there and the presence of perennial crops, from livestock farmers. 
On this basis we drew up a typology of six types of pioneer front farmers ${ }^{1}$. These are described in terms of the distinction forming axis 1 of the PCA (Principal Component Analysis).

- Types 1, 5 and 6 are people who mainly live on agriculture. Type 1 farmers ( 21 cases) are the wealthiest respondents; they are livestock farmers, have the largest farms and most frequently employ agricultural workers. Type 5 farmers (18 people) have mixed farms with annual crops, perennial crops and cattle raising. Type 6 farmers (19 people) specialise in annual crops.

- Types 2, 3 and 4 are farmers with an other activity than agriculture. Type 2 (39 people) mainly focuses on livestock over small areas (less than $50 \mathrm{ha}$ ) where annual crops are also sometimes grown. Type 3 (17 people) are people with several activities who tend to live on large farms: they have very little income from farming but rent out grazing lands to others. Those in type 4 (39 people) derive most of their farm income from annual crops.

The key to understanding this information is not the policy applied at each site: our analysis seeking to account for the variability of production systems according to the locality where the respondent lives was significant only for $11.7 \%$ of the variability observed, while the fact that a farmer has benefited from a particular technical assistance programme was not significant at all in accounting for the type of production concerned (or for the above typology).

\section{4-3. Socio-economic characteristics of the families surveyed}

As with the production system analyses (and in the same three sites), we used questionnaires designed to characterise around 50 beneficiaries of agrarian reform in each site. These characteristics are shown in Table 2. We used different types of variables: demographic (to describe the composition of the household), biographical (geographic and professional mobility) and finally the level of schooling achieved by the respondent. The data used to construct these variables were collected by means of a biographical questionnaire (Courgeau and Lelièvre, 1996), which, for each year of a person's life, provides data describing their residence, family status and professional status. The demographic, migratory and professional variables were synthesised by means of two types of multivariate analysis:

- The demographic variables, which varied widely, were analysed into multiple components to obtain temporal data for the respondent, including age at the birth of their first child, number of children they had by 30 years of age, number of children per person and number of their marital partnerships,

- For the residential and professional mobility variables, we conducted a multivariate analysis per type of mobility using data expressed in years of life and synthesised by means of a qualitative philharmonic analysis (Barbary and Pinzon Sarmiento, 1998), as already performed in the Amazonian context (Arnauld De Sartre and Sebille, 2008)2.

\footnotetext{
${ }^{1}$ The division into categories is based on a calculation of distance in the PCA. The division into six categories produced the best possible compromise between the number of categories and the variance accounted for $(37 \%$ of variance)

${ }^{2}$ The annual variable was taken as the calendar year (and not the age of the person), with years grouped into decades for the purposes of the analysis. For the residence variables, we built up two binomial categories (urban/rural, region/not in the region); professional variables were defined by sector (seven types: agriculture, domestic help, Garimpo, non-agricultural, not known, no activity and no data), ditto professional status (seven types again: domestic help, student, share-out revenue (such as sharecroppers), independent, employed, no
} 
Table 2, describing the different patterns found for each of the typologies, shows the profiles of agrarian reform beneficiaries. The majority had settled many years previously in Amazonia, their experience was predominantly rural (only $8 \%$ lived in towns before coming to the assentamentos), $38 \%$ of the respondents had already owned land before arriving in the survey area, $22 \%$ were agricultural workers who had become landowners under the agrarian reform programme, and the same percentage had been employed in different sectors of activity before becoming landowners. The other farmers either did not provide information on their professional careers (these were often women) or were former gold prospectors. Demographically speaking, our data confirm that Amazonia has indeed entered a demographic transition, but unevenly depending on families (Arnauld De Sartre, Guétat and Diniz-Guerra, 2006). On the basis of these analyses, we produced a typology of agrarian reform beneficiaries with six categories ${ }^{3}$.

- The first category, and the largest ( 40 people, or $28 \%$ of respondents), is made up of traditional peasant families: low level of schooling (illiterate or primary school level), pre-transition demographic profile, predominantly rural experience in Amazonia. Most of these people had owned land before moving to the study sites.

- The second category is made up of 35 people with comparable migratory and professional the mobility profiles (though with less experience of the region and rural society), but with smaller families and a higher level of schooling. This group includes many younger people.

- The other four categories together include as many people as the first two: the third (12 people) mainly comprises women, or young people living alone in a rural environment after previous experiences in agricultural or domestic employment; the fourth category (16 people) is made up of former farm workers who now own land (and whose family profiles are the same as in category $2)$; the fifth (16 people) comprises rural people who had experienced high professional and geographical mobility but with quite varied family profiles (equal numbers of two of the 1 and 2 types); the sixth category (18 people) is made up of former gold prospectors with highly variable migratory, family and schooling profiles, who now own land and had recently benefited from agrarian reform.

Finally, few of the farmers match the classic agrarian reform profile in which the beneficiaries are former farm workers (corresponding to type 4). Among those with varied itineraries now living for an indefinite time in agrarian reform localities, we found families who were continuing to work as agricultural migrants as described elsewhere (Wanderley, 1998; Arnauld De Sartre, 2006). Furthermore, we observed that farmers' profiles did not really differ according to the settlement projects where they live: the extractive producers at Maçaranduba had a comparable profile to those affiliated to the Palmares landless peasant movement (if we discount the fact that this site has most of the former gold prospectors belonging to type 6), who in turn are comparable to the isolated farmers at travessão 338-South, who enjoy very little support.

\section{4-4. Quality of life}

Finally, we attempted to characterise the quality of life of the communities at each site. Building up an indicator such as this is a complex matter as quality of life is by definition difficult to quantify. However, it is justified provided that the methodology is very clear and that the results are considered simply as indicators. We built up the indicators through a two-stage analysis: firstly, we used the results of a previous study on indicators of satisfaction among frontier family farmers (Arnauld de Sartre, 2006); secondly, we tried to translate these general indicators into easily quantifiable

activity and no data). Finally, for both variables, we also included the number of times each person entered or

left a status category.

${ }^{3}$ The same method was used for production systems, for which we used six categories $(30 \%$ of variance accounted for). 
indicators. We chose two quality of life components: a material component defined in terms of household amenities and a social component defined in terms of social networks. Previous research showed that indicators for schooling, geographical stability or professional status could have been chosen, but these are already measured in the sociographic typology. The components were built up as follows:

- Material component. Seven indicators based on household amenities: housing quality, hygiene and cooking facilities, electricity, consumer goods, ownership of a refrigerator, means of travel and media equipment. These indicators are in turn made up of 15 subindicators, which are described in Table 3 along with the weighting applied to each.

- The social network component is built up from four indicators: grouped settlement, proximity of family members, access to towns and having a residence in town ${ }^{4}$. Table 4 shows the sub-indicators and weighting methods used to build up this component.

As with as the previous data, a multivariate analysis was performed for each of the 11 indicators. Axis 1 , which contains $32 \%$ of the information, clearly distinguishes between families whose quality of life is dependent, or not dependent, on collective amenities. Axis 2, which contains $16 \%$ of the information, shows families where individual amenities are the most important factor. Axis 1 shows families with both ready access to town and well-built housing (construction materials, hygiene and ready access to electricity): these are usually houses built by Brazilian Federal State for beneficiaries of agrarian reform. The owners of these houses tend to live in villages of several houses (often the case under agrarian reform); their inhabitants sometimes belong to an association but they are fairly distant from other family members. Families along axis 2 are those where individual household equipment are the important factor: consumer goods, media and means of transport.

This typology in five categories distinguishes people first by their place of residence and secondly by their personal equipment: type 1 (39 people) comprises those who live in remote locations and have few collective or individual amenities, but whose community life is organized around family networks, as with patterns of spontaneous colonisation. The next two categories are families who live in localities with collective amenities of a fairly high standard (accessibility and electricity), but whose access to some of these amenities (electricity and well-built housing) depends on individual incomes (the higher-income families are in type 3,14 people, and the poorest in type 2, 35 people); family networks are more important than social networks (associations, etc.). Families of type 4 and 5 have access to a high standard of collective infrastructure (accessibility, grouped settlements) and very good housing, but their equipment divides them into two subgroups, one with a high standard of equipment (17 people) and one with little equipment (32 people). For these two types, communal life is organised around associations and unions.

\section{4-5. Factors accounting for typologies and localities}

The same type of analysis was performed for all four sets of data, i.e. a multivariate analysis associated with a typology of individuals (in the case of the three socio-economic datasets). In order to

${ }^{4}$ We built up indicators describing the fact of belonging to networks intentionally developed for a particular purpose, such as religious groups, social movements or small producers' associations (usually associated with agrarian reform benefits). However, these indicators could not distinguish between family farmers, because although many farmers declared that they belonged to such a group (the MST for instance, or a producer association), this did not signify that they were active within these groups. For these reasons, the statistical analysis showed that no significant discrimination between family farmers was possible if based on such indicators. 
test the explanatory power of the local scale in the structure of each dataset, we performed an interclass analysis to segment the variance accounted for within the datasets and thus bring out the effects of each locality on the structure of the datasets (Dolédec et Chessel, 1987). In order to compare the explanatory power of the local scale with the typology of individuals, we proceeded in the same way with the typologies analysed for the three socio-economic datasets. The results are shown in Table 5.

This analysis shows an obvious difference in the explanatory power of each site: the state of the environment dataset is the one whose structure is most affected by the local scale, followed by quality of life. On the other hand, the local scale has little effect on the structure of the production and sociographic datasets, especially the latter. It can be seen that this is not due to the structure of the data, as the typology of production systems or social types can considerably reduce the observed variance. These are the results we will now try to explain.

\section{Discussion. Scales and patterns of sustainable development}

The link between land use trends and agrarian systems on the one hand and the characteristics of policies applied in each site on the other hand is not immediately obvious. The situation clearly differs between the two sites where policies combining obligatory land-holding and extractive practices have been applied. Except in Pacajá, where no policy was applied, the policies developed in each site were supposed to have a positive impact on the environment: in the Palmares site, they consisted of conventional means of support for sustainable agrarian reform: new infrastructure (access to farms for road vehicles, new housing), loans for production (mainly for permanent crops and livestock) and technical assistance. In Maçaranduba, the policies supported forest fruit extraction and imposed collective land ownership. The policy applied in the PDS was based not only on these two principles (collective ownership and extractive activities), but also on collective timber management and extraction, limitations on livestock raising and deforestation and technical assistance, etc. Nevertheless, the results are very different to what was expected. At Maçaranduba, the environmental status characteristics show some of the worst rates of degradation of all the sites studied, while at Boa Esperança, the environmental status is favourable. On the other hand, the two agrarian reform sites have intermediate rates of environmental degradation, whereas the site where no policies are applied (338-South) has a better conservation status than the one under a sustainable agrarian reform policy.

For the sites for which we collected individual farm data, two points stand out: on the one hand, the quality of life of the communities is directly linked both to the deforestation rate and to the scale of the public policies applied in these sites. On the other hand, production systems and population characteristics are relatively independent of the sites in both cases. The latter point indicates that individual family farmer characteristics do not significantly account for their social or political success.

These points raise four questions: about scales of sustainable development, about the difficulty of bringing alternative practices for environmental resource use into general use, about the diffusion of sustainable practices among populations and, finally, about the value of collective regulation of sustainable development projects.

\section{5-1. Scales of sustainable development}

The contrast between localities with rather different patterns of local resource use but fairly homogeneous population profiles raises the question of the scale of sustainable development policies. Policies are implemented at the national scale but the patterns that emerge from their application at regional and local scales vary widely.

The regional scale seems to have great importance. The sites are on either side of the boundary between Eastern and Central Amazonia, and the fact that the two most deforested sites are to the east and the two best preserved sites to the west is unlikely to be a matter of chance. Remoteness from the Trans-Amazonian highway and a major city probably does more for environmental conservation than any policy applied - or not applied. This means that success of a sustainable development policy must be assessed in the light of regional dynamics. This is not easy to do by statistical means in the two sites to the east, as these projects have been established in forest fragments, and because of this are in 
a better state of conservation than their surrounding environment. In terms of overall dynamics, however, they are on a trajectory that, if maintained, will bring them into line with regional dynamics in the short term. Regarding the two sites to the west of the zone, it can be seen that while the 338South site has very similar deforestation rates to those of surrounding localities, the PDS site is noticeably better protected than its neighbours.

This difference indicates that within these regional subgroups, obviously, the local scale is important. The different rates of deforestation in the travessão 338-South site and the Boa Esperança PDS are clearly related to the application of different policies. But applying different policies is not always enough. For example, in the subregion to the east, the Maçaranduba project, in terms of environmental protection, is an obvious failure. It has to be said that, in addition to the policy applied there to support extractive production, foresters in the subregion have been exerting pressure in favour of logging - pressure that resulted in the assassinations mentioned earlier. This locality is on a scale that would allow a coherent policy to be applied over a continuous area (Albaladejo and Veiga, 2000): the State of Brazil has understood this, since one of the conditions for obtaining the status of an agrarian reform area is that a local coherence plan must be applied.

The picture as it stands suggests a situation where the regional and local scales function like filters for tensions and/or opportunities, both creating a momentum that drives the reality observed in the sites.

\section{5-2. Difficulties in establishing alternative cultivation methods and strategy for safeguarding livestock production}

In economic terms, our analyses showed the difficulties involved in establishing alternatives to slash-and-burn agriculture. The multivariate analysis of agricultural production systems in the sites shows that most farms have a number of basic features in common: annual crops combined with cattle, associated with either perennial crops or external income. This is the situation in the farms of types 2 and 5, which include one farm out of three. On this basis, farms become increasingly specialised: when farm specialisation is associated with higher incomes and the farmers have been established for a long time, specialisation is usually towards cattle raising (type 1); farmers who have settled recently and/or have lower incomes tend to specialise in annual crops. Income from activities other than farming is then usual, as the poorest farmers rent out available grazing areas on their lands.

Farms rarely specialise in perennial crops. Similarly, none of the farmers depend exclusively on extractive activities, which only account for a small portion of total farm incomes. But perennial crops and extractive production are the two priority activities identified to curb deforestation, because annual crops generally involve short-rotation slash-and-burn methods (where cropfields give way to grazing areas after one or two crop cycles), while cattle need a great deal of space ( 0.5 head each year for $250 \mathrm{~kg}$ of fodder per hectare in the localities studied).

The system obviously has its own logic, which has often been explained: although livestock farming requires a lot of space, it does not need much labour; cattle are a form of savings on the hoof, insofar as livestock prices tend to keep pace with inflation and animals can be sold in case of need. However, there is another more deep-seated logic: establishing intensive production systems in Amazonia is meaningless insofar as land availability is perceived as infinite (and on the scale of individuals, this is indeed the case). As comparative studies of agriculture have shown, intensifying production without the need to do so in terms of resources and when the labour is not available is an aberration (Mazoyer and Roudart, 1997). Changing agricultural practices depends on changing access to land - by drastically limiting it. But in Amazonia, problems with declining soil fertility are usually resolved by moving on to more fertile zones, not by changes in practice.

Both sustainable development projects attempted to make a change in access to lands: the farmers were not supposed to have any individual title to land but only a right of enjoyment. This meant that they were encouraged to change their practice by the fact that they were not allowed to sell their land to move elsewhere: the alternative techniques proposed (extraction or perennial crops) were associated with limited access to land and a ban on livestock and logging. However, these rules were applied only within the Boa Esperança PDS, where there is no livestock: although we have no economic data on 
farms, satellite images show that there are virtually no grazing lands in the PDS. But these limitations are not popular with the local populations: collective ownership, control on the possibility to sell one's land, limitations to deforestation, were perceived as unjust limitations by family farmers (Arnauld De Sartre, Berdoulay and Lopes, 2011).

\section{5-3. Ways of resolving collective land ownership and internal conflicts}

As we have said, the logic driving local populations in each site is fairly similar. We emphasise three points here: the professional, migratory and social dynamics of families, which account in part for the overall dynamics observed.

About a third of the farmers became owners of farmland for the first time thanks to the agrarian reform applied in the locality where we met them. Another third had always owned their land, and the remaining third is made up of people with a much more complex history (but always tending towards rural livelihoods). Land ownership is always very important for those who have been landless for a long time. Keeping or acquiring landowner status is a major explanatory factor of the migrations observed among these farmers.

Looking into the causes of migration among farmers, we found that aside from migration due to violence or family problems (divorce, for example) and a minority of cases where farmers did not explain their reasons for migration, two of the reasons frequently given are migration to achieve a new professional status (as a landowner) and/or migration of an entire family to find land elsewhere, often where the whole family can be involved in farming. Acquiring or keeping landowner status is very important for farmers along the pioneer front. This explains the reluctance towards collective land ownership observed in the Maçaranduba and Boa Esperança PDS. The plan in both sites was to establish a system of land rights drawing directly on the system in extractive reserves used by socalled traditional Amazonian populations, where each family has a right of enjoyment to a land parcel that prevents the family from selling it. But these systems were never established, as the farmers completely rejected the idea of having no individual rights over their land and being unable to sell at least the "beneficios" that might accrue from it.

Furthermore, the very different histories of the people we met suggest that they are driven by a different individual logic and culture. When these farmers are severely constrained, for example by the obligation to adopt sustainable practices (whose advantages over livestock raising are by no means patent, at least in retrospect), their reactions to these constraints can be very different. Conflicts inevitably arise within the localities, and they can be serious: for example, in the Boa Esperança PDS and at Maçaranduba, a conflict arose between those wanting to abide by the sustainable production rules of the site where they settled and those who refused to abide by rules that prevented them from selling timber or raising livestock. But these different logics play inside a site, and not among sites, and are related to the history of each family, its political beliefs and values.

The way these conflicts were resolved brings us to our final considerations on the chances of establishing more sustainable productive practices in these sites. At Maçaranduba, these conflicts remained internal to the project for a long time, as people felling timber in the zone were able to sell it while using their settlement plots as they wished. The situation was much more tense at Boa Esperança: the assassination of the founder, the charismatic Sister Dorothy, brought the project to the attention of the authorities, while some inhabitants decided to "give meaning to her death" by preventing anyone from disobeying the rules of the PDS. This caused a position to build up locally between those wanting to protect "the soul of the PDS" against those who wanted freedom to use its environment as they wished. The conflict crystallised when some inhabitants wanted to sell their timber to local logging companies and were opposed by those wanting to abide by the rules (on this conflict, see in particular Arnauld De Sartre, Berdoulay and Lopes, 2011). Their opposition was manifested by a road block, which forced the authorities to intervene before the demonstrators could be chased off by a group of thugs. Since then, the state authorities have set up sentry boxes manned around the clock by guards whose role is to prevent illegal timber extraction.

As this conflict gained strength locally and became highly visible in the region, nationally and even internationally, it gave a voice to the claims of the local populations. However, the "victory" won 
by those defending sustainable uses of the environment is relative. The situation cannot endure in the longer term and cannot be emulated: it is impossible for rules or environmental standards to be enforced by security forces over the long term and in an area with such a dense network of forest tracks as Amazonia. In this sense, compliance with the rules in the PDS seems to be more revealing of problems with sustainable production than proof that these alternatives are viable.

\section{Conclusion}

To understand the conditions for the success or failure of projects attempting to reconcile environmental conservation with agricultural production (land-sharing practices) for local populations living in a high-stakes areas, we compared two projects for sustainable settlement and two classic agrarian reform projects in the Brazilian Amazon. To make the comparison, we developed methods to describe, at local and farm scale, deforestation rates, production systems, population characteristics and living conditions within the study zones. The sampling criterion we used was the difference in policies applied in each of the areas, but it was striking to see how widely the different localities diverged in the directions taken, and how unpredictable their divergence was in terms of the policies applied.

Our analysis has produced widely differing results: one of the sustainable development sites turns out to have much higher rates of deforestation than those with classic development projects, while conservation results for the other sustainable development sites are very favourable - but achieved at the cost of unequal acceptance among the local population. Three main points underline the difficulties involved in reconciling production and conservation. The first is the determining influence of national and regional contexts. While sustainable production projects are often designed for the local scale, this scale carries little weight in terms of regional dynamics. The influence of context is such that sustainable development policies cannot be isolated from a system of scales, where what happens at the local scale cannot be considered independently from what is happening at other scales. This is due in particular to the enormous difficulty of disseminating alternatives to slash-and-burn cultivation on a large scale, since the very point of slash-and-burn is not only to allow one or two annual crop cycles but also to establish extensive grazing lands. Furthermore, the local populations, with their history of migration in search of lands they can own, are often not particularly inclined to accept environmental conservation constraints.

An alliance between land-sharing practices and family farmers can therefore in no way be taken for granted in the Brazilian Amazon. It demands not only a very proactive policy but also effective appropriation by local populations, which we observed in our study only in one situation that, in many respects, was the exception that confirms the rule. 
Figure 1 -Brazilian Amazonia divided according to the Amazônia Sustentável program

\section{Figure 2 - Location of study sites}

A/ Location of study sites within the Amazon Basin. B/ Location of study sites within the Pará State. C/ Location of study sites along the deforestation arc. D/ Maçaranduba site. E/ Palmares site. F/ Travessão 338-South site. G/ Boa Esperança site.

Figure 4 - Land use dynamics between 1990 and 2007 in the four study sites 
Table 1 - Farming variables

\begin{tabular}{|c|c|c|c|c|c|c|}
\hline & \multicolumn{3}{|c|}{ Description } & \multicolumn{3}{|c|}{ Multivariate analysis } \\
\hline & Min. & Ave. & Max. & $\begin{array}{c}\text { Dim.1 } \\
(22.5 \%)\end{array}$ & $\begin{array}{c}\operatorname{Dim} .2 \\
(15.5 \%)\end{array}$ & $\begin{array}{c}\operatorname{Dim.3} \\
(\mathbf{1 1 . 5 \%})\end{array}$ \\
\hline Size (HA) & 15 & 63 & 275 & 0.3869 & -0.424 & 0.5209 \\
\hline Time since arrival (years) & 0 & 10.5 & 29 & 0.31 & -0.3829 & 0.4866 \\
\hline Family labour (full-time equivalent) & 0 & 1.476 & 4.8 & 0.3601 & -0.033 & -0.397 \\
\hline $\begin{array}{l}\text { Number of employees per property (full-time } \\
\text { equivalent) }\end{array}$ & 0 & 0.08 & 1 & 0.4345 & 0.2057 & 0.3113 \\
\hline Total gross income $(\mathrm{R} \$)$ & 0 & 2469 & 18927 & 0.9158 & 0.2437 & 0.0784 \\
\hline Non-agricultural income* & 0 & 0.35 & 1 & -0.4867 & -0.2177 & -0.0151 \\
\hline Gross income beef* & 0 & 0.38 & 1 & 0.5061 & -0.6309 & -0.3853 \\
\hline Gross income cow's milk* & 0 & 0.01 & 0.43 & 0.0602 & 0.0019 & -0.2295 \\
\hline Gross income other livestock* & 0 & 0.11 & 1 & -0.1649 & -0.0468 & 0.3087 \\
\hline Gross income annual crops* & 0 & 0.3 & 1 & -0.2384 & 0.7294 & -0.0597 \\
\hline Gross income perennial crops* & 0 & 0.06 & 1 & -0.076 & -0.0142 & 0.57 \\
\hline $\begin{array}{l}\text { Labour productivity (gross income per full- } \\
\text { time family job) }\end{array}$ & 0 & 1043 & 10515 & 0.8249 & 0.3432 & 0.1696 \\
\hline $\begin{array}{l}\text { Land productivity (gross income per } \\
\text { deforested ha) }\end{array}$ & 0 & 114 & 1129 & 0.3203 & 0.7609 & -0.0495 \\
\hline $\begin{array}{l}\text { Large livestock unit ( } \mathrm{n}^{\circ} \text { heads for } 250 \mathrm{~kg} \\
\text { fodder per ha) }\end{array}$ & 0 & 0.717 & 3.9 & 0.6245 & -0.2664 & -0.4146 \\
\hline
\end{tabular}


Table 2 - Variables for the sociographic analysis

\section{Migratory}

M1 99 Entirely rural background and established for at least 20 years in eastern Amazonia, and for a long time in the localities investigated

M2 15 Fairly marked urban background outside the region in the 1980s, arrival in the 1990s and establishment of rural livelihood

M3 11 Urban, recent arrival in the localities investigated

M4 12 Arrival in the 1990s, alternating rural and urban livelihoods

\section{Professional}

P1 53 Farmers with strong farming traditions, no experience of salaried work and longstanding owners of their land

P2 32 High professional mobility in agricultural and non-agricultural sectors

P3 31 Strong farming identity, but not as landowners

P4 13 No farming identity but garimpo or other; professional mobility only once (to start farming)

P5 8 Don't know or no data: women

\section{Demographic}

D1 20 People past child-bearing age. Families with three or four children born to a fairly elderly couple.

D2 32 Traditional family with many children (6 to 10) born at a fairly early childbearing age.

D3 41 People at mid-childbearing age with three to four children.

D4 27 Large families with 4 to 6 children, but born at a relatively late childbearing age.

D5 17 Young people with no children or very young first child.

\section{Schooling}

S1 $32 \quad$ Illiterate

S2 64 Primary school

S3 $\quad 32 \quad$ Middle school

S4 9 6th form college - university 
Table 3 - Quality of life indicators and sub-indicators - material aspects

\begin{tabular}{|c|c|c|c|}
\hline Indicator & Variable & Type & Weighting \\
\hline \multirow{11}{*}{ Housing quality } & \multirow{5}{*}{ Roof } & Zinc & 0.75 \\
\hline & & Plant material & 0.25 \\
\hline & & Wood & 0.5 \\
\hline & & Tiles & 1 \\
\hline & & Tiled & 1 \\
\hline & \multirow{4}{*}{ Floor } & Earth & 0.25 \\
\hline & & Wood & 0.5 \\
\hline & & Cement & 0.75 \\
\hline & & Earth & 0.25 \\
\hline & \multirow[t]{2}{*}{ Walls } & Wood & 0.5 \\
\hline & & Cement & 1 \\
\hline \multirow{2}{*}{ Electricity } & & Yes & 1 \\
\hline & & No & 0 \\
\hline \multirow{13}{*}{$\begin{array}{l}\text { Hygiene and } \\
\text { cooking }\end{array}$} & \multirow{4}{*}{ Sanitation } & None & 0 \\
\hline & & Septic tank & 1 \\
\hline & & Toilet & 0.5 \\
\hline & & Latrine & 0.25 \\
\hline & \multirow{5}{*}{ Source of water } & Public network & 1 \\
\hline & & Well & 0.75 \\
\hline & & River & 0.25 \\
\hline & & Lake & 0.25 \\
\hline & & Rainwater & 0 \\
\hline & \multirow{4}{*}{ Cooking fuel } & Electricity & 1 \\
\hline & & Wood & 0.25 \\
\hline & & Gas & 0.75 \\
\hline & & Charcoal & 0.5 \\
\hline \multirow{6}{*}{ Media } & \multirow{2}{*}{ Television } & Yes & 1 \\
\hline & & No & 0 \\
\hline & \multirow{2}{*}{ Radio } & Yes & 1 \\
\hline & & No & 0 \\
\hline & \multirow{2}{*}{ Telephone } & Yes & 1 \\
\hline & & No & 0 \\
\hline \multirow{6}{*}{ Consumer goods } & \multirow{4}{*}{$\begin{array}{l}\text { Washing } \\
\text { machine } \\
\text { Electrical } \\
\text { appliances }\end{array}$} & Yes & 1 \\
\hline & & No & 0 \\
\hline & & Yes & 1 \\
\hline & & No & 0 \\
\hline & \multirow{2}{*}{ Sound system } & Yes & 1 \\
\hline & & No & 0 \\
\hline \multirow{2}{*}{ Refrigerator } & & Yes & 1 \\
\hline & & No & 0 \\
\hline \multirow{6}{*}{$\begin{array}{l}\text { Means of } \\
\text { transport }\end{array}$} & \multirow{2}{*}{ Car } & Yes & 4 \\
\hline & & No & 0 \\
\hline & \multirow{2}{*}{ Motorcycle } & Yes & 2 \\
\hline & & No & 0 \\
\hline & \multirow{2}{*}{ Bicycle } & Yes & 0.5 \\
\hline & & No & 0 \\
\hline
\end{tabular}


Table 4 - Quality of life indicators and sub-indicators - social aspects

\begin{tabular}{|c|c|c|}
\hline Indicator & Sub-indicator & Coef. \\
\hline \multirow{2}{*}{$\begin{array}{l}\text { Grouped } \\
\text { dwellings }\end{array}$} & Yes & 1 \\
\hline & No & 0 \\
\hline \multirow{6}{*}{ Accessibility } & Over $4 \mathrm{~km}$ on foot & 0.1 \\
\hline & $\begin{array}{l}\text { Less than } 4 \mathrm{~km} \text { on foot (and more } \\
\text { than } 500 \mathrm{~m} \text { ) }\end{array}$ & 0.25 \\
\hline & $\begin{array}{l}\text { No walking track and more than } \\
20 \mathrm{~km} \text { on unpaved road }\end{array}$ & 0.5 \\
\hline & $\begin{array}{l}\text { No walking track and less than } 20 \\
\mathrm{~km} \text { on unpaved road }\end{array}$ & 0.75 \\
\hline & $\begin{array}{l}\text { Tarmac all the way and close to } \\
\text { town }\end{array}$ & 1 \\
\hline & $\begin{array}{l}\text { Tarmac all the way and far from } \\
\text { town }\end{array}$ & 0.75 \\
\hline $\begin{array}{l}\text { Distance from } \\
\text { family }\end{array}$ & Migratory network index & 1 \\
\hline \multirow{6}{*}{$\begin{array}{l}\text { Participation in a } \\
\text { social network }\end{array}$} & \multirow{2}{*}{ Political } & Yes: 1 \\
\hline & & No: 0 \\
\hline & \multirow{2}{*}{ Religious } & Yes: 1 \\
\hline & & No: 0 \\
\hline & \multirow{2}{*}{ Communal tasks } & Yes: 1 \\
\hline & & No: 0 \\
\hline
\end{tabular}


Table 5 - Comparative analysis between scales and typologies

$\begin{array}{llll}\text { Environment } & \text { Society } & \text { Production } & \text { Quality-of-life }\end{array}$

\begin{tabular}{|c|c|c|c|c|}
\hline $\begin{array}{l}\text { Perc. of variance } \\
\text { accounted for by } \\
\text { the local scale }\end{array}$ & $27.7 \%$ & $4.4 \%$ & $11.7 \%$ & $24.3 \%$ \\
\hline $\begin{array}{l}\text { Perc. of variance } \\
\text { accounted for by } \\
\text { the typology }\end{array}$ & & $30 \%$ & $37 \%$ & $46.8 \%$ \\
\hline
\end{tabular}




\section{Bibliography}

Albaladejo, C. and Tulet, J.C., Editors, 1996. Les fronts pionniers d'amazonie brésilienne. L'harmattan, Paris.

Albaladejo, C. and Veiga, I. Dir., 2000. A construção local dos territórios da agricultura familiar (Amazônia, Nordeste). Revista Agricultura familiar, 1 (2 e 3), Universidade Federal Do Pará, pp. 142152.

Albaladejo, C. and Arnauld De Sartre, X. Dir., 2005. L'amazonie brésilienne et le développement durable. L'Harmattan, Paris.

Arnauld De Sartre, X., 2006. Fronts pionniers d'Amazonie. CNRS Éditions, Paris.

Arnauld De Sartre, X. and Sébille, P., 2008. Diversité des itinéraires migratoires des colons d'un front pionnier amazonien. Confins, 4 , http://Confins.Revues.Org/.

Arnauld De Sartre, X. and Taravella, R., 2009. National sovereignty vs. sustainable development. Lessons from the narrative on the internationalization of the Brazilian Amazon. Political Geography, 28 (7), pp. 406-415.

Arnauld De Sartre, X. and Berdoulay, V., 2011. Des politiques territoriales durables? Leçons d'Amazonie. Éditions Quae, Paris.

Arnauld De Sartre, X., Guétat, H. and Diniz-Guerra, G., 2006. Contrôle de la natalité et changement social des familles paysannes de fronts pionniers d'Amazonie orientale brésilienne. Autrepart (39), pp. 21-38.

Arnauld De Sartre, X., Berdoulay, V. and Lopes, R.D.S., 2011. Eco-frontier and place-making: the unexpected transformation of a sustainable settlement project in the amazon. Geopolitics, 16 (4), pp. 578-606.

Barbary, O. and Pinzon Sarmiento, M.L., 1998. L'analyse harmonique qualitative et son application à la typologie des trajectoires individuelles. Mathématiques et Sciences Humaines (144), pp. 29-54.

Brown, J.C. and Purcell, M., 2005. There's nothing inherent about scale: political ecology, the local trap and the politics of development in the brasilian Amazon. Geoforum, 36 (7), pp. 607-624.

Castellanet, C., Simões, A., and Filho, P. C. (1998). Diagnóstico Preliminar da Agricultura Familiar na Transamazônica: Indicações para pesquisa e desenvolvimento. Empresa Brasileira de Pesquisa Agropecuária, Belém.

Courgeau, D. and Lelièvre, E., 1996. Changement de paradigme en démographie. Population, 51 (3), pp. 645-654.

Davidson, E.A., Araujo (De), A.C., Artaxo, P., Balch, J.K., Brown, F.I., Bustamante, M.M.C., Coe, M.T., Defries, R.S., Keller, M., Longo, M., Munger, W., Schroeder, W., Soares Filho, B.S., Souza Junior, C., Wofsy, S.C., 2012. The Amazon Basin in transition. Nature, 481, pp. 321-328.

De Reynal, V., Muchagata, M., Topall, O. and Hébette, J., 1997. Des paysans en Amazonie, In: Théry, H., Editor, 1997. Environnement et développement en Amazonie brésilienne. Belin, Paris.

Dolédec, S. and Chessel, D., 1987. Rythmes saisonniers et composantes stationnelles en milieu aquatique. I - Description d'un plan d'observation complet par projection de variables. Acta Ocologica, 8 (3), pp. 403-426.

Governo federal do Brasil, 2007, Plano Amazônia sustentável, Governo Federal, Brasilia, 101 p.

Green, R.E., Cornell, S.J., Scharlemann, J.P.W., Balmford, A., 2005. Framing and the fate of wild nature. Science 307, 550-555.

Hébette, J., 1996. Parenté, Voisinage et organisation professionnelle dans la formation du front pionnier amazonien. In: Albaladejo C. and Tulet J.C., Editors, 1996. Les Fronts pionniers de l'amazonie brésilienne, L'Harmattan, Paris.

Laurance, W., Cochrane, M., Gergen, S., Fearnside, P., Delamonica, P., Barber, C., d'Angelo, S. and Fernandes, T., 2001. The future of the brasilian amazon. Science, 291 (5503), pp. 438-444.

Le Tourneau, F.-M., Droulers, M., Editors, 2011. L'Amazonie brésilienne et le développement durable. Belin, Paris.

Mazoyer, M., Roudart, L., 1997. Histoire des agricultures du monde. Seuil, Paris.

Mello, N.A., 2011. Les politiques publiques de développement durable. In: Droulers M. and Le Tourneau F.-M., Editors, 2001. L'Amazonie brésilienne et le développement durable. Belin, Paris. 
Oszwald, J., Lefebvre, A., Arnauld De Sartre, X., Thales, M. and Gond, V., 2010. Analyse des directions de changement des états de surface végétaux pour renseigner la dynamique du front pionnier de maçaranduba (Pará, Brésil) entre 1997 et 2006. Télédétection, 9 (2), pp. 97-111.

Pacheco, P., 2009a. Smallholder livelihoods, wealth and deforestation in the Eastern Amazon. Human Ecology 37 (1), 27-41.

Pacheco, P., 2009b. Agrarian Reform in the Brazilian Amazon: Its Implications for Land Distribution and Deforestation. World Development 37 (8), 1337-1347.

Phalan, B., Onial, M., Balmford, A., Green, R.E., 2011. Reconciling Food Production and Biodiversity Conservation: Land Sharing and Land Sparing Compared. Science 333 (6047), 1289-1291.

Rodrigues, A.S.L., Ewers, R.M., Parry, L., Souza Junior, C., Veríssimo, A. and Balmford, A., 2009. Boom-and-bust development patterns across the amazon deforestation frontier. Science, 324, pp. 1435-1437.

Simmons, C., Walker, R., Perz, S., Aldrich, S., Caldas, M., Pereira, R., Leite, F., Fernandes, L.C. and Arima, E., 2010. Doing it for themselves: direct action land reform in the Brazilian Amazon. World Development, 38 (3), pp. 429-444.

Simmons, C.S., 2004. The political economy of land conflict in the eastern Brazilian Amazon. Annals of the association of American geographers, 94 (1), pp. 183 - 206.

Simmons, C.S., Walker, R.T., Arima, E.Y., Aldrich, S.P. and Caldas, M.M., 2007. The Amazon land war in the south of Pará. Annals of the association of american geographers, 97 (3), pp. 567 - 592.

Soares Filho, B.S., Nepstad, D., Curran, L., Coutinho Cerqueria, G., Garcia, R.A., Azevedo Ramos, C., Voll, E., Mcdonald, A., Lefebvre, P. and Schlesinger, P., 2006. Modelling conservation in the amazon basin. Nature, 440 (23), pp. 520-523.

Taravella, R. and Arnauld De Sartre, X., 2012. The symbolic and political appropriation of scales: a critical analysis of the amazonian ranchers' narrative. Geoforum, 43 (3), pp. 645-656.

Théry, H., 1996. L'Amazonie, dernier boom brésilien? In: Albaladejo C., Tulet J.C., Editors, 1996.

Les Fronts Pionniers d'Amazonie. L'Harmattan, Paris, pp. 354-359.

Velho, O.G., 1972. Frentes de expansão e estrutura agrária. Zahar Editores, Rio De Janeiro.

Walker, R., Simmons, C., Aldrich, S., Perz, S., Arima, E. and Caldas, M., 2011, The Amazonian Theater of Cruelty, Annals of the Association of American Geographers, 101, p. 1156-1170.

Wanderley, M.D.N., 1998. Raízes históricas do campesinato brasileiro. In: Tedesco J.C., Editor, Agricultura Familiar: Realidades e Perspectivas. EDIUPF, Passo Fundo. 